\title{
Considerations on the Toxicity of Brilliant Blue FCF Aqueous Solutions before and after Ozonation
}

\author{
MARIA MARCVART TIRON ${ }^{1}$, IRINA EUGENIA LUCACIU ${ }^{2}$, MIHAI NITA-LAZAR ${ }^{2}$, \\ STEFANIA GHEORGHE ${ }^{2 *}$ \\ ${ }^{1}$ Politehnica University of Bucharest, Faculty of Applied Chemistry and Materials Science, Department of Analytical \\ Chemistry and Environmental Engineering, no. 1-7, Polizu Str., 011061, Bucharest, Romania \\ ${ }^{2}$ National Research and Development Institute for Industrial Ecology ECOIND Bucharest, Biotests- Biological Analyses \\ Laboratory, 71-73 Drumul Podu Dambovitei Str., 060652, Bucharest, Romania
}

\begin{abstract}
The food dyes have a potential toxic effect on aquatic organisms which trigger the necessity of their removal from industrial or urban wastewaters. Many different removal methods were investigated for this purpose, but the ozonation and advanced oxidation processes (AOPs) were successfully applied in this field. However, the majority of studies emphasized that color removal by ozonation process did not report a complete mineralization of the dye and the resulted by-products may have a greater toxicity than the original compound. In this context, the paper presents a comparative ecotoxicity study of the dye Brilliant Blue FCF (BB FCF) before and after ozone treatment. The BB FCF toxic effect, before and after ozonation was investigated on crustacean (Daphnia magna), lethal or inhibitory concentrations for 50\% of tested organisms (LC50 / EC50) were used to estimate the effect level. The dye showed no toxicity on crustacean $(C L 50 / C E 50>100 \mathrm{mg} / \mathrm{L})$ before ozonation. The ozonized solutions presented a high toxicity for crustaceans compared to initial dye due to the by-products occurrence.
\end{abstract}

Keywords: Brilliant Blue FCF, ozonized by-products, toxicity, aquatic life.

\section{Introduction}

Synthetic dyes are widely used in many industries such as food, textiles, rubber, paper, plastics and in other daily used products. About 7.000 to 10.000 different commercial dyes and pigments are produced annually all around the world. Food manufacturers prefer synthetic dyes, because they produce a stronger color than natural colorings with a lower cost [1]. Brilliant Blue FCF (BB FCF) is a synthetic dye component of the triphenylmethane compounds with the molecular formula: C37-H36N2-O9-S3.2Na [2]. The most commonly used synonyms in published literature are: Brilliant Blue FCF, Acid Blue 9, Alphazurine FG, E133, Erioglaucine disodium salt, FD\&C; Blue no. 1, etc. [3]. These are used as food dyes in ice-cream, candies, drinks and other sweets.

Also it is often used in cosmetic, textile fields and in different research applications to detect the water infiltration in soil [4], for microbial fluorescent or blood cell staining [5, 6]. Sometimes, they are used in medicine for eye surgery and detecting lung aspiration in critically ill patients [7, 8]. In addition, BB FCF is an inhibitor of the Panx 1 channels and it could be useful for the treatment of Crohn's, Acquired Immunodeficiency Syndrome (AIDS), melanoma, epilepsy, neurotrauma, inflammation, stroke and injuries to the central nervous system $[9,10]$.

Before 1993, the BB FCF dye has been forbidden in eleven European countries but after EU foundation this has been certified as a safe food additive [11]. The number of BB FCF in Alimentarius Codex (updated 2019) is E133. In 2017 based on a rat's intoxication study, the acceptable daily intake (ADI) for human was established to $0-6 \mathrm{mg} / \mathrm{kg}$ body weight $[12,13]$.

\footnotetext{
*email: stefania.gheorghe@incdecoind.ro
} 
In the medicinal uses, BB FCF dye is absorbed only $5 \%$ and $95 \%$ is excreted. Nowadays there is an ongoing controversy regarding the safety of this artificial food dye [14]. Numerous studies reported toxic effects on animals or human such as: convulsion, tumors of gastrointestinal origin and lymphoma in rodents [8]; increase of hepatic enzymes and bilirubin level in animal model [14]; oxidation of thyroid peroxidase forming aromatic amines (carcinogens) [15]; purinergic signaling (implicated in several cellular functions: proliferation of neural stem cells, vascular reactivity, apoptosis and cytokine secretion, mediating the effects of neural activity during development, neurodegeneration, inflammation, neuropathic pain and cancer) [10, 16]; attention deficit and hyperactivity in children [11]; cumulative absorption through lingual mucosa and through skin [17]. An alert of toxicity was launched by scientists and FDA regarding the BB FCF absorption and its lethal toxicity in three critically ill patients [18].

The dyes chemicals industry is under Regulation (EC) No 1907/2006 (REACH) [19] and must meet the criteria concerning the human and animal safety using the standardized methodologies for testing. The impact assessment of chemicals on the aquatic environment is described in the Regulation (EU) No 286/2011 [20] amending Regulation (EC) No 1272/2008, for the purposes of its adaptation to classification, labelling and packaging of chemical substances/mixtures legislation to Global Harmonized System of United Nations (GHS).

It has been estimated that about $10-15 \%$ of all the industrial dyes are released into the wastewater effluents $[18,21]$ during the dyeing process. Small amounts of dye can affect aquatic life and the entire food chain either by direct chemical / biological effect or by reducing the light transmission [15, 21]. Unfortunately, the present technology of WWTP cannot solve this dye issue and new wastewater treatment technologies are needed to improve the dye removal amount and subsequently to improve the water quality of the final effluents [22 - 24]. Various methods for BB FCF wastewater purification have been developed: physical methods - ultra sonication, ultrafiltration, micro- and nanofiltration or photocatalytic degradation, coagulation - flocculation, sorption, ion exchange membranes, electrochemical processes; chemical methods - oxidative processes (electrochemical oxidation, ozonation, advanced oxidation processes - AOPs), precipitation, complexation; biological methods aerobic/ anaerobic degradation, use of fungi, algae and microbial fuel cells [14, 21, 25, 26].

The AOPs generating powerful oxidants have emerged as an important and cheaper class of technologies for the removal of organic contaminants from wastewater, and for remediation of organic contaminants in polluted soil and groundwater. These oxidation methods use oxidants like $\mathrm{K}_{2} \mathrm{~S}_{2} \mathrm{O}_{8}$, $\mathrm{KBrO}_{3}, \mathrm{KIO}_{4}$, Fenton's reagent, photo Fenton, $\mathrm{H}_{2} \mathrm{O}_{2}$ and ozone [22, 27].

Ozone may oxidize the organic and inorganic compounds from waste waters [27] but the resulted effluents has been shown to increase the general toxicity of the water for the rainbow trout larvae and reduce the immune responses in rainbow trout [22, 27-30].

Related to the known structure of the BB FCF dye (Figure 1), a concern is the potential formation of toxic ozonolysis by-products (Table 1). These by-products would require subsequent post-ozonation treatment for their removal [26, 31-34].

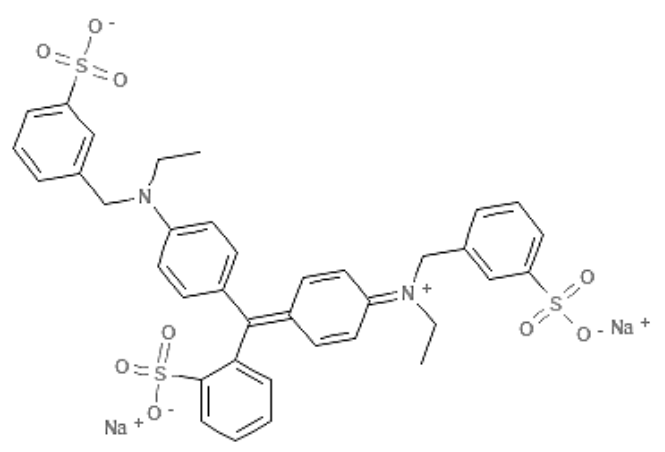

Figure 1. The Brilliant Blue molecule [35] 
The paper goal was to evaluate the BB FCF ecotoxicity, specifically on aquatic life, before and after ozonation process. Acute aquatic toxicity [32] is normally determined using a fish model (testing 96-hours, LC50), a crustacean species (testing for 48-hours, EC50) and/or an algal species (testing for 72 or 96-hours, EC50. These species cover a range of trophic levels and taxa and are considered as surrogate for all aquatic organisms [20].

Our study was focused on the effect of BB FCF on planktonic crustaceans (Daphnia magna). The efficiency of ozonation process for color removal was evaluate based on the aquatic organism safety.

Table 1. BB FCF ozonation process and its by-products [28, 31-34, 36]

\begin{tabular}{|c|c|c|}
\hline BB FCF oxidation type & Matrix & By-products \\
\hline Electrochemical oxidation & Aqueous Solution of $\mathrm{NaX}$ & $\begin{array}{l}\text { Ethanol, Acetaldehyde, Acetic acid, glyoxylic acid, } \\
\text { formic acid }\end{array}$ \\
\hline Ozone-based discoloration & Aqueous solution & $\begin{array}{l}\text { N-(2-hydroxypropyl) benzene sulfonamide; } \\
\text { 5-Sulfooxymethylfurfural; } \\
\text { 2-Sulfobenzoic acid; } \\
\text { 2-formylbenzenesulfonic acid }\end{array}$ \\
\hline $\begin{array}{l}\text { Ozone-based discoloration (simple } \\
\text { mass-transfer, } \\
\text { temp/pH) non-adjusted } \\
\end{array}$ & Waste fruit leather & $\begin{array}{l}\text { Carbonyl compounds (hexanal, ethanol, } \\
\text { benzaldehyde, } 2 \text {-furfural) }\end{array}$ \\
\hline $\begin{array}{l}\text { Ozone-based discoloration (simple } \\
\text { mass-transfer, } \\
\text { temp/pH) non-adjusted }\end{array}$ & $\begin{array}{l}\text { Wastewater (ozonized fruit leather) } \\
\text { solution / suspension) }\end{array}$ & $\begin{array}{l}\text { Ethanal, propanal, butanal, pentanal, hexanal, octanal, } \\
\text { acetone, 2-heptanone, } \\
\text { benzaldehyde }\end{array}$ \\
\hline AOP & Wastewater containing food dyes & Aromatic amines, phenolic compounds \\
\hline
\end{tabular}

\section{Materials and methods}

\subsection{Chemicals and equipment's}

The dye BB FCF, analytical grade (CAS 3844-45-9), was purchased from Sigma Aldrich. The $1000 \mathrm{mg} / \mathrm{L}$ concentration of the dye stock solution was prepared in distilled water. Ozonation process was performed on solutions concentrations (prepared from stock solution) in the range of $1-50 \mathrm{mg} / \mathrm{L}$ BB FCF. An OZONOSAN Alpha-Plus Generator with medical oxygen was use. The continuous measurement of ozone concentration $\left(1-130 \mathrm{mg} \mathrm{O}_{3} / \mathrm{L}\right.$ gaseous mixture $\left.-\mathrm{g} . \mathrm{m}\right)$ was assured by UVPhotometer that accessorized the generator. Under a constant oxygen flow rate, the ozone dose was constant. The batch experiments of $100 \mathrm{~mL}$ were carried out using HEILDORPH VIBRAMAX 100 orbital shaker. $\mathrm{H}_{2} \mathrm{SO}_{4} 0.1 \mathrm{M}$ was use to adjusted the solutions $\mathrm{pH}$. An ORION 290A pH-meter was used for $\mathrm{pH}$ monitoring. The BB FCF final concentrations in the aqueous samples were detected using a CINTRA 404 UV/VIS Spectrometer. The maximum absorption wavelength of $630 \mathrm{~nm}$ was chosen to be used in the quantitative discoloration of BB FCF.

The laboratory BB FCF toxicity tests with invertebrates (crustaceans as Daphnia) were performed using reagents and growth media supplied by MicroBiotests Belgium.

\subsection{Ozonation process}

The experiment of the dye discoloration efficiency using ozonation in term of yield (\% $\left.\mathrm{R}_{\mathrm{BB}}\right)$ was performed at ambient temperature using various concentrations of BB FCF, in range of $1-50 \mathrm{mg} / \mathrm{L}$. All solutions were treated with the same dose of ozone $(200 \mathrm{mg} / \mathrm{L} \mathrm{g.m}$.) for a contact time of 300 seconds, under continuously stirring $(200 \mathrm{rpm})$. The experiment was fulfilled mostly at $p \mathrm{H}$ of BB FCF solution $(p \mathrm{H}=7.05)$, excepted those where the influence of $\mathrm{pH}$ was evaluated when the tests were done at a $p \mathrm{H}=4.03$. Ozonation of dye samples was carried in glass recipients. Every time a volume of $100 \mathrm{ml}$ of dye solution with different concentrations was added into the glass recipient. Ozone gas dose was supplied, followed by aeration for $5 \mathrm{~min}$ to remove residual ozone.

To evaluate the dye removal efficiency, the following formula was applied: 
where

$$
\% R_{B B}=\left(1-C_{i B B} / C_{t B B}\right) \times 100
$$

$C_{i B B}=$ the initial dye concentration at time $(\mathrm{t})=0$

$C_{t B B}=$ the dye concentration at time $(\mathrm{t})$.

\subsection{Ecotoxicity test}

The laboratory toxicity tests were executed using dye solutions prepared into a mineral medium, in the concentration range of $0.1-100 \mathrm{mg} / \mathrm{L}$ (starting to a stock solution of $1000 \mathrm{mg}$ dye dissolved in 1000 $\mathrm{mL}$ distillated water), to estimate the median effective concentration (EC50) expected to produce a certain effect of BB FCF in $50 \%$ of test organisms, in a given population under a defined set of conditions. BB FCF - effluents obtained after ozonation process (range of $1-50 \mathrm{mg} / \mathrm{L}$ ) were tested under various physical and chemical work conditions. The ozonized solutions were tested undiluted and $50 \%$ vol. diluted, with or without adjusted $\mathrm{pH}$ using $1 \mathrm{M} \mathrm{NaOH}$ or $\mathrm{HCl}$. The median effective concentration (EC50) was estimated.

The Daphnia magna were directly exposed to the BB FCF solutions in a test batch within a continuous period of exposure of 48hrs, in accordance with OECD test 202 [37], Table 2.

The test conditions (temperature, $\mathrm{pH}$ and dissolved oxygen) were periodically monitored using a multiparameter WTW tip Multi 350i. The tests were performed in replicates for each tested concentration and control to ensure statistically relevant results.

Table 2. Toxicity test

\begin{tabular}{ccccc}
\hline Species & Test & Type of test & Endpoint effect & $\begin{array}{c}\text { Test period / } \\
\text { incubation }\end{array}$ \\
\hline Daphnia magna & $\begin{array}{c}\text { OECD 202 } \\
\text { DAPTOXKIT F }\end{array}$ & Static, acute & $\begin{array}{c}\text { Mortality / immobilization, LC50/ } \\
\text { EC50 }\end{array}$ & $24-48 \mathrm{~h}, 20^{\circ} \mathrm{C}$ \\
\hline
\end{tabular}

\section{Results and discussions}

\subsection{Ozonation treatment of BB FCF}

Color removal $\left(\% \mathrm{R}_{\mathrm{BB}}\right)$ in presence of various experimental conditions was around $96-99 \%$ for all BB FCF concentrations using similar ozone treatment in a neutral or acid $\mathrm{pH}$ media (Table 3). In case of BB FCF concentrations 1, 2.5, 5 and $10 \mathrm{mg} / \mathrm{L}$ and acid $\mathrm{pH}$ (4.03), the \% $\mathrm{R}_{\mathrm{BB}}$ was $\geq 99.5 \%$ (Table 3) indicating a good discoloration of ozonized solutions [26]. The acute toxicity of all ozonized solutions was tested in various conditions, such as: $\mathrm{pH}$ correction (in the range of $6.5-8.5$ ) or 50\% vol. dilutions.

Table 3. Characterization of BB FCF solutions used in toxicity tests and $\% \mathrm{R}_{\mathrm{BB}}$

\begin{tabular}{|c|c|c|c|c|}
\hline \multirow[b]{2}{*}{$\begin{array}{c}\text { BB FCF } \\
\text { Concentration } \\
(\mathrm{mg} / \mathrm{L})\end{array}$} & \multicolumn{3}{|c|}{ Treatment conditions } & \multirow[b]{2}{*}{$\% \mathbf{R}_{\mathrm{BB}}$} \\
\hline & pH & $\begin{array}{c}\mathrm{O}_{3} \\
\text { Concentration } \\
\text { (mg/L g. m, ) }\end{array}$ & $\begin{array}{c}\text { Contact } \\
\text { Time } \\
\text { (seconds) }\end{array}$ & \\
\hline \multirow{2}{*}{1} & 7.05 & 200 & 300 & 99.92 \\
\hline & 4.03 & 200 & 300 & 99.94 \\
\hline \multirow{2}{*}{2.5} & 7.05 & 200 & 300 & 99.81 \\
\hline & 4.03 & 200 & 300 & 99.87 \\
\hline \multirow{2}{*}{5} & 7.05 & 200 & 300 & 99.68 \\
\hline & 4.03 & 200 & 300 & 99.74 \\
\hline \multirow{2}{*}{10} & 7.05 & 200 & 300 & 98.80 \\
\hline & 4.03 & 200 & 300 & 99.50 \\
\hline \multirow{2}{*}{30} & 7.05 & 200 & 300 & 97.66 \\
\hline & 4.03 & 200 & 300 & 98.94 \\
\hline \multirow{2}{*}{50} & 7.05 & 200 & 300 & 96.82 \\
\hline & 4.03 & 200 & 300 & 97.04 \\
\hline
\end{tabular}




\subsection{Toxicity of BB FCF dye}

The experiments on conventional and alternative test batteries represents a reliable way of estimation the complex and significant effects of chemicals on the entire food chain [38-40].

Microbiotests performed with Daphnia or green algae are being applied more and more often to evaluate the inhibitory effects of chemicals, the current trend in the field of ecotoxicology being the abandonment or reduced use of vertebrate aquatic organisms (fish) [19, 40, 41, 42].

Daphnia magna (Cladocera) are small aquatic crustaceans commonly called water fleas. Daphnia was selected for ecotoxicity testing because crustacean are the most sensible aquatic organisms to pollutants toxicity, particularly useful because of its short life and good and rapid reproduction. There are still at least two reasons why Daphnia was selected for dye toxicity testing: a) to avoid any errors of results in the algal growth inhibition test due to the blue color of BB FCF that may cause interference; b) fish tests supposed a large number of organisms and this is in contradiction with international recommendations concerning vertebrate use.

All the acute toxicity tests were performed for BB FCF dye solutions in concentration range 0.1$100 \mathrm{mg} / \mathrm{L}$. The BB FCF aqueous solutions (from 0.1 to $100 \mathrm{mg} / \mathrm{L}$ ) whiteout any treatment reveled nontoxic effects for planktonic crustaceans, having only minor lethal/inhibitory effects (5-20\%) on Daphnia magna after $48 \mathrm{~h}$ of incubation (Table 4). The EC50>100 mg/l indicate non harmful impact of the dye on these organisms. Similar results on Daphnia magna were reported for BB FCF between $97 \mathrm{mg} / \mathrm{L}$ to $>1000 \mathrm{mg} / \mathrm{L}$ by the international data bases for chemical registration such as Ecotoxicology knowledgebase (ECOTOX) [43] and other Environmental Organization [44].

According to Regulation on the classification categories for substances hazardous to the aquatic environment [20], the BB FCF is classified as nontoxic for crustacean species (Daphnia)(EC50>100 $\mathrm{mg} / \mathrm{L})$.

Table 4. Acute toxicity results of BB FCF on Daphnia magna after 48h of contact

\begin{tabular}{|c|c|c|c|c|}
\hline \multirow{2}{*}{$\begin{array}{l}\text { Solutions } \\
\text { whiteout treatment }(\mathrm{mg} / \mathrm{L} \\
\text { BB FCF) }\end{array}$} & \multicolumn{2}{|c|}{ Average of: } & \multirow[b]{2}{*}{$\begin{array}{l}\text { Acute effect } \\
(\%)\end{array}$} & \multirow{2}{*}{$\begin{array}{l}\text { Toxicity } \\
\text { EC50 - mg/L } \\
\text { / REACH } \\
\text { classification }\end{array}$} \\
\hline & $\mathrm{pH}$ & $\begin{array}{l}\text { Dissolved oxygen } \\
\mathrm{mgO}_{2} / \mathrm{L}\end{array}$ & & \\
\hline 100 & 7.60 & 8.62 & 20 & \multirow{8}{*}{ EC50 >100 mg/L } \\
\hline 50 & 7.03 & - & 20 & \\
\hline 20 & 7.35 & - & 15 & \\
\hline 10 & 7.35 & - & 10 & \\
\hline 5 & 7.42 & - & 10 & \\
\hline 1 & 7.38 & - & 5 & \\
\hline 0.1 & 7.32 & - & 0 & \\
\hline $\begin{array}{l}\text { Control } \\
\text { (dilution media) }\end{array}$ & 7.14 & 8.91 & 0 & \\
\hline
\end{tabular}

\subsection{Toxicity of BB FCF ozonized solutions}

Daphnia toxicity tests were performed for BB FCF solutions treated with ozone in different conditions (ozone treated solutions $\mathrm{pH} 7$; ozone treated solutions with acidification $p \mathrm{H} 4$; ozone treated solutions $p \mathrm{H} 4$ with $p \mathrm{H}$ correction and 50\% vol. diluted ozone treated solutions with $p \mathrm{H}$ correction, to correspond to toxicity test conditions).

Figure 2 presented the results of acute toxicity of BB FCF ozonized solutions on Daphnia. The data shown an increased toxicity in case of ozonized samples comparing with the untreated BB FCF solutions. The toxicity results of ozonized samples were 5-10 fold higher than untreated samples. The ozone treatment corroborated with the acidification process improved the blue color of BB FCF removal, but increased their toxicity due to the high oxidation that can lead to by-products, potentially more toxic that the initial compound. The ozonized and acidified solutions at $\mathrm{pH} 4$ reveled a maximum toxicity $(100 \%)$ due to acid $\mathrm{pH}$ effect on organisms living. Similar results were also reported in other studies which highlighted an efficient discoloration of the dye and a by-products formation [45-46]. A 
greater ecotoxicity against Artemia salina was observed after ozonation of BB FCF solutions leading to the conclusion that the occurred by-products are more toxic that their precursors itself [31].

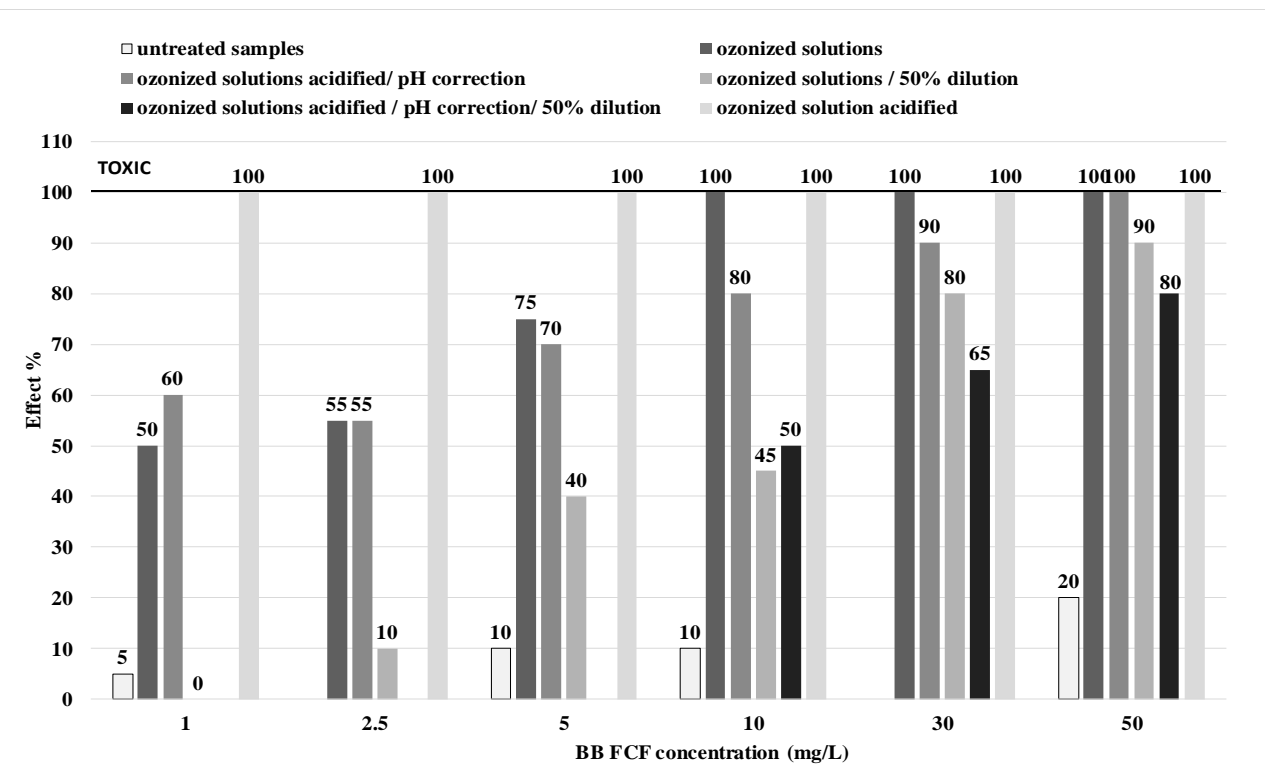

Figure 2. Acute toxicity of ozonized BB FCF solutions on planktonic crustaceans

The toxicity of ozonized samples decreased when they were $50 \%$ diluted, but even so their toxicity remained higher than untreated solutions (case of 5, 10, 30 and $50 \mathrm{mg} / \mathrm{L} \mathrm{BB} \mathrm{FCF}$ ). The same trend of toxicity was also observed in case of ozonized and acidified solutions with $\mathrm{pH}$ correction and $50 \%$ vol. diluted.

BB FCF ozonized solutions and 50\% vol. diluted reveled inhibitory /lethal effects between $0 \%$ and $100 \%$ on Daphnia, the level of toxicity being lower than undiluted samples. The median effective concentration - EC50(48h) of ozonized and 50\% vol. diluted samples was estimated at $4.8 \mathrm{mg} / \mathrm{L} \mathrm{BB}$ FCF (Figure 3). This value indicated that BB FCF solutions resulting after ozone treatment have had acute toxicity effects, with possible long lasting harmful effects to aquatic life.

Our previous studies shown significant toxic effect ( $80 \%$ mortality) of BB FCF solutions in concentration of $5 \mathrm{mg} / \mathrm{L}$ and $10 \mathrm{mg} / \mathrm{L}$ ozonized (200 $\left.\mathrm{mg} \mathrm{O}_{3} / \mathrm{L}\right)$, under stirring condition (200 rpm) and acidified ( $\mathrm{pH} 4$ ) [26]. The toxicity effects decreased to $45-50 \%$, after diluting these solutions in proportion of $50 \%$ with distilled water. This fact leads us to conclusion that the toxic effects can be diminished when the ozonized dye solutions do not exceed the concentration of $10 \mathrm{mg} / \mathrm{L}$ and are diluted with water in proportion of $50 \%(1: 1 \mathrm{v} / \mathrm{v})$, in a $\mathrm{pH}$ range of $6.5-8.5$. Also, smaller concentration of BB FCF $(\leq 5 \mathrm{mg} / \mathrm{L})$ subject to ozone treatment and diluted $50 \%$ could cause much lower toxicity to aquatic organisms (10-40\% mortality). 


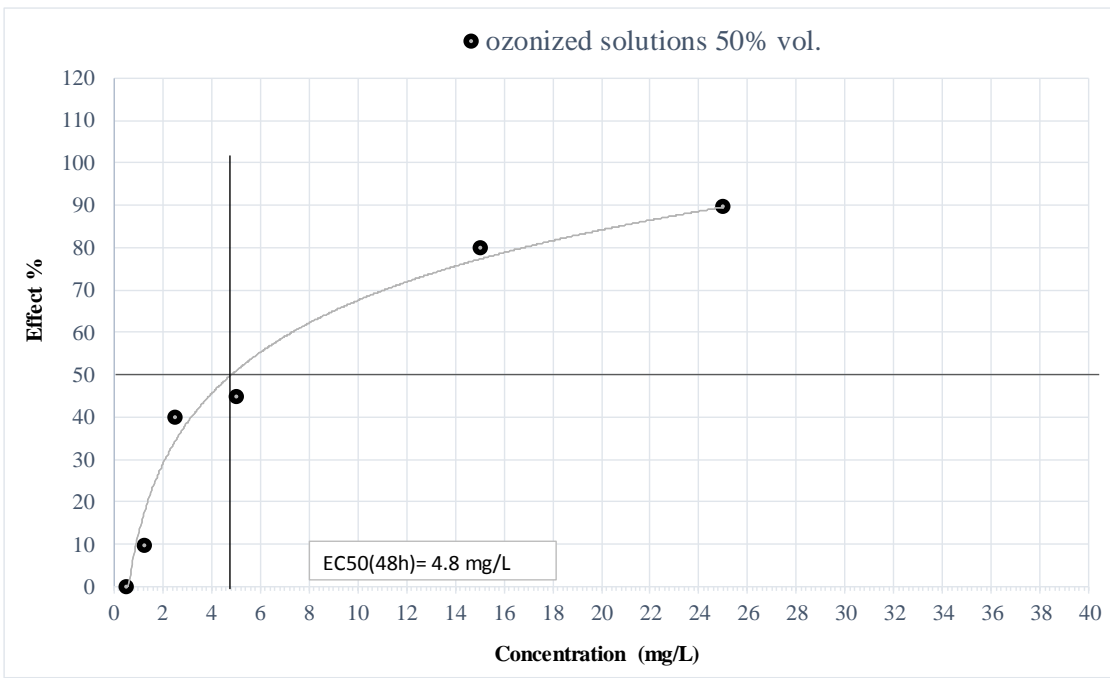

Figure 3. EC50(48h) estimation for BB FCF

ozonized solutions $50 \%$ vol. diluted

Some studies on BB FCF degradation shown that color removal was not completed by the total mineralization of dye and the incidence of degradation compounds such as aromatic amines could be a problem for the living organisms [47]. Considering the Predicted Environmental Concentrations (PEC) estimated for BB FCF in surface water about $<0.1$ to $626 \mu \mathrm{g} / \mathrm{L}$ (in accordance with the economic sector - industrial, food, cosmetics) [44], the estimated toxicity level could be reduced about 100 times in the field. A PNEC (Predicted No Effect Concentration) value of $0.15 \mathrm{mg} / \mathrm{l}$ taking in to consideration 6 species of a taxonomic group [44].

\section{Conclusions}

The paper presented a comparative ecotoxicity study of the BB FCF dye on Daphnia magna, before and after the ozone treatment process, meant to eliminate the blue color. The dye at various aqueous solutions induced no toxicity / inhibitory effects on crustacean species (EC50>100 mg/L).

The $200 \mathrm{mg} \mathrm{O}_{3} / \mathrm{L}$ ozone treated solutions of BB FCF highlighted color efficiency removed more than $90 \%$, but very significant toxic effects on Daphnia magna was observed (perhaps due to the fact that by-products were more toxic than initial compound).

In order to discharge dye solutions without toxic effects on aquatic life, the ozone treatment of the BB FCF in concentration $\leq 10 \mathrm{mg} / \mathrm{L}$ must be supplemented by other processes such as $\mathrm{pH}$ adjustment and aqueous dilutions greater than $50 \%$ vol.

Acknowledgements: The authors thanks for financial support offered by The National Nucleu Program through contract no 20N/2019, Project code PN 19040201.

\section{References}

1.O'NEIL, M.J. (ed.), The Merck Index - An Encyclopedia of Chemicals, Drugs, and Biologicals. Whitehouse Station, NJ: Merck and Co., Inc., 2006, 225-231.

2.***Sigma - Aldrich Corporation, Aldrich Chemistry 2009-2010: Handbook of Fine Chemicals. Milwaukee, WI: 2010, 1239-1240.

3.***https://chem.nlm.nih.gov/chemidplus/name/brilliant\%20blue\%20fcf (accessed on 04.12.2019).

4.ROPER, M.M., DAVIES, S.L., BLACKWELL, P.S., HALL, M.D.J., BAKKER, D.M., JONGEPIER, R., WARD, P.R., Management options for water-repellent soils in Australian dryland agriculture, Soil Res., 53, 2015, 786-806.

5.CHAU, H.W., GOH, Y.K., SI, B.C., VUJANOVIC, V., An innovative brilliant blue FCF method for fluorescent staining of fungi and bacteria, Biotech. Histochem., 86(4), 2011, 280-287. 
6.DE OLIVEIRA, A.M.JR., LEMOS, T.M.A.M., DE S. DANTAS, D., DE FARIAS, R.F., Food dyes as blood cell dyes : An experimental and molecular modelling study to brilliant blue FCF and brown HT, Pharm. Chem. J., 3(4), 2016, 17-22.

7.***National Library of Medicine, SIS - ChemIDplus Lite Record for Brilliant Blue (3844-45-9). June 23, 2001.

8.LUCARELLI, M.R., SHIRK, M.B., JULIAN, M.W, COUSER, E.D., Toxicity of food drug and cosmetic blue no. 1 dye in critically ill patients, Chest, 125(2), 2004, 793-795.

9.WANG, J., JACKSON, G.D., DAHL, G, The food dye FD\&C Blue No. 1 is a selective inhibitor of the ATP release channel Panx1, J. Gen. Physiol., 141(5), 2013, 649-656.

10.FERREIRA, L.G.B., FARIA, R.X., DA SILVA-FERREIRA, N.C., SOARES-BEZERRA, R.J., J., Brilliant Blue Dyes in Daily Food: How Could Purinergic System Be Affected?, Int. J. Food Sci., 16, 2016, 1-13.

11.KIRAN N., Chemistry of food colors, https://www.coursehero.com/file/22468529/colorspdf (accessed on 10.11.2019)

12.WHO Technical Report Series 1007, Evaluation of certain food additives, Eighty-fourth report of the Joint FAO/WHO Expert Committee on Food Additives, 2017, 9-14.

13.***http://www.fao.org/gsfaonline/additives/details.html?id=111 (accessed on 25.11.2019).

14.BORZELLECA, J.F., DEPUKAT, K., HALLAGAN, J.B., Lifetime toxicity / carcinogenicity studies of FD \& C Blue No. 1 (brilliant blue FCF) in rats and mice, Food Chem. Toxicol., 28(4), 1990, 221-234.

15.ZEINAB, A.A., OGARITE, A.Y., MOUHIADDINE, M.ELJ., Kinetic study of acid blue 1 discoloration with persulfate, J. Chem. Technol. Metall., 52(5), 2017, 812-824.

16.EL-WAHAB, H.M.F.ABD, EL-DEEN MORAM, G.S., Toxic effects of some synthetic food colorants and / or flavor additives on male rats, Toxicol. Ind. Health, 29(2), 2013, 224-232.

17.LUCOVÁ, M., HOJEROVA, J., PAŽOUREKOVÁ, S., KLIMOVÁ, Z., Absorption of triphenylmethane dyes Brilliant Blue and Patent Blue through intact skin, shaven skin and lingual mucosa from daily life products, Food Chem. Toxicol., 52, 2013, 19-27.

18.MALONEY, J.P., RYAN, T.A., BRASEL, K,J., BINION, D.G., JOHNSON, D.R., HALBOWER, A.C., FRANKEL E.H., NYFFELER, M., MOSS, M., Food dye use in enteral feedings: a review and a call for a moratorium., Nutr. Clin. Pract., 17(3), 2002, 169-181.

19.REGULATION (EC) No 1907/2006 of the European Parliament and of the Council of 18 December 2006 concerning the Registration, Evaluation, Authorization and Restriction of Chemicals (REACH), entered into force on 1 June 2007.

20.COMMISSION REGULATION (EU) no 286/2011 of 10 March 2011 amending, for the purposes of its adaptation to technical and scientific progress, Regulation (EC) No 1272/2008 of the European Parliament and of the Council on classification, labelling and packaging of substances and mixtures.

21.***https://www.intechopen.com/books/water-chemistry/contamination-of-water-resources-byfood-dyes-and-its-removal-technologies, (accessed on 25.11.2019).

22.BEIJER, K., BJORLENIUS, B., SHAIK, S., LINDBERG, R.H., BRUNSTR, B., BRANDT, I., Removal of pharmaceuticals and unspecified contaminants in sewage treatment effluents by activated carbon filtration and ozonation: Evaluation using biomarker responses and chemical analysis, Chemosphere, 176, 2017, 342-351.

23.MARIN, N.M., TIRON, O., PASCU, L.F., COSTACHE, M., NITA-LAZAR, M., BADEA, I.A., Synergistic Methodology Based on Ion Exchange and Biodegradation Mechanisms Applied for Metal Complex Dye Removal from Waste Waters, Rev. Chim., 69 (1), 2018, 38-44.

24.STOICA, C., VASILE, G.G., BANCIU, A., NICULESCU, D., LUCACIU, I.E, NITA-LAZAR, M., Influence of Anthropogenic Pressures on Groundwater Quality from a Rural Area, Rev. Chim., 68 (8), 2017, 1744-1748. 
25.ZAVASTIN, D. E., GHERMAN, S., CRETESCU, I., Removal of direct blue dye from aqueous solution using new polyurethane - cellulose acetate blend micro-filtration membrane, Rev. Chim., 63(10), 2012, 1075-1078.

26.MARCVART, M., CONSTANTIN, C., STOICA, L., Discoloration of food dyes from aqueous media by ozonation, case study: Brilliant Blue, U.P.B. Sci. Bull., Series B, 81(3), 2019, 119-130.

27.VON GUNTEN, U., Ozonation of drinking water: part I. Oxidation kinetics and product formation, Water Res., 37(7), 2003, 1443-1446.

28.VAIANO, V., IERVOLINO, G., RIZZO, L., SANNINO, D., Advanced oxidation processes for the removal of food dyes in wastewater, Curr. Org. Chem., 21(12), 2017, 1068-1073.

29.PORTJANSKAJA, E. Ozone science and technology - Ozone reactions with inorganic and organic compounds in water, Encyclopedia of Life Support Systems (EOLSS), 24-28.

30.DAVIDSON, J., GOOD, C., WELSH, C., SUMMERFELT, S., The effects of ozone and water exchange rates on water quality and rainbow trout Oncorhynchus mykiss performance in replicated water recirculating systems, Aquacul. Eng., 44 (3), 2011, 80-96.

31.DA SILVA, J.C., BISPO, G.L., PAVANELLI, S.P., AFONSO, R.J., AUGUSTI, R., Ozonation of the food dye Brilliant Blue in aqueous medium: monitoring and characterization of products by direct infusion electrospray ionization coupled to high-resolution mass spectrometry, Rapid Commun Mass Spectrom., 26(11), 2012, 1305-1310.

32.ZHU, W., Ozone-Based Decolorization of Food Colorants: Characterization and Application to Fruit Leather Recycling, Graduate Theses and Dissertations Graduate College 2010, https://lib.dr.iastate.edu/cgi/viewcontent.cgi?article=2747\&context=etd (accessed on 04.12.2019).

33.ZHU, W., KOZIEL, J.A., CAI, L., ÖZSOY H. D., VAN LEEUWEN, J. (HANS), Quantification of Carbonyl Compounds Generated from Ozone-Based Food Colorants Decomposition Using On-Fiber Derivatization-SPME-GC-MS, Chromatogr., 2, 2015, 1-18.

34.SHINNOSUKE, O., KOZIEL, J.A., JENKS, W.S., CAI, L., RICE S., HANS VAN LEEUWEN, J., Ethanol purification with ozonation, activated carbon adsorption, and gas stripping. Sep. Purif. Technol., 151, 2015, 165-171.

$35 * * *$ https://pubchem.ncbi.nlm.nih.gov/compound/19700 (accessed on 04.12.2019).

36.TUTUNARU, B., Spectrophotometry and Electrochemistry of Brilliant Blue FCF in Aqueous Solution of NaX, Int. J. Electrochem. Sci., 12(1), 2017, 396-412.

37.OECD Guidelines for the Testing of Chemicals. Daphnia sp., Acute Immobilisation Test, 2004.

38.GLAZE, W.H., Reaction Products of Ozone: A Review, Environ. Health Perspect., 69, 1986, 151157.

39.GHEORGHE, S., LUCACIU, I., STANESCU, E., STOICA, C., Romanian aquatic toxicity testing strategy under REACH, J. Environ. Prot. Ecol., 14 (2), 2013, 601-611.

40.GHEORGHE, S., LUCACIU, I., PAUN, I., VASILE, G.G., PETRE, J., IANCU, V.I., STOICA, C., MITRU, D., NITA-LAZAR, M., Romanian Journal of Ecology \& Environmental Chemistry, 1 (1), 2019, 26-38.

41.GHEORGHE, S., PETRE, J., LUCACIU, I., STOICA, C., NITA-LAZAR, M., Risk screening of pharmaceutical compounds in Romanian aquatic environment, Environ. Monit. Assess., 188(6), 2016, $379,1-16$.

42.GHEORGHE, S., STOICA, C., LUCACIU, I., BANCIU, A., NITA-LAZAR, M., Ecotoxicity of biocides (chemical disinfectants) - lethal and sublethal effects on non-target organisms, Rev. Chim., 70(1), 2019, 307-312.

43.***https://cfpub.epa.gov/ecotox (accessed on 04.12.2019)

44.***https://www.canada.ca/content/dam/eccc/documents/pdf/pded/triarylmethanes/Draft-screening-

assessment-triarylmethanes-group.pdf, Draft Screening Assessment Triarylmethanes Group, Environment and Climate Change Canada Health Canada, December 2018 (accessed on 04.12.2019). 45.SUBRAMANIAN, S. M., Sustainable Fibers and Textiles, The Textile Institute Book Series, Woodhead Publishing; 1 edition, June 21, 2017. 
46.DE LUNA, L.A.V., DA SILVA, T.H.G., NOGUEIRA R. F P., DE ARAGÃO G.U., Aquatic toxicity of dyes before and after photo-Fenton treatment, J. Hazard. Mater., 276C, 2014, 332-338.

47.GOSETTI, F., GIANOTTI, V., ANGIOI, S., POLATI, S, MARENGO, E., GENNARO, M.C., Oxidative degradation of food dye E133 Brilliant Blue FCF Liquid chromatography-electrospray mass spectrometry identification of the degradation pathway, J. Chromatogr. A, 1054(1-2), 2004, 379-387.

Manuscript received: 24.12 .2019 